\title{
Nigeria and conflict resolution in Africa: The Darfur experience*
}

\author{
Nigeria y la resolución de conflictos en Africa: La experiencia de \\ Darfur
}

Recibido: 01 de octubre de 2011 - Revisado: 07 de octubre de 2011 - Aceptado: 10 de noviembre de 2011

Joseph C. Ebegbulem**

\begin{abstract}
Conflicts in Africa have over the years led to loss of lives, displacement of persons and misery in many parts of the continent. The need to resolve, manage and prevent these conflicts, and equally deal with the socio-economic challenges arising from these conflicts has become a source of worry to African nations including Nigeria, the giant of Africa. It is in the light of the foregoing therefore, that this paper attempts to analyze Nigeria's role in conflict resolution in Africa using the Darfur crisis in Sudan as a case study. The paper examines the historical background of the Darfur conflict and efforts made by Nigeria to resolve the crisis through peace initiatives. Since the restoration of peace in Darfur is a big challenge facing the African continent, the paper looks at the problems and prospects of peace in that part of the continent.

The paper concludes by positing that even though Nigeria has demonstrated its commitment in resolving the conflict in Darfur, there still is a lot to do in concert with the African Union, especially now that Southern Sudan is a sovereign state. Key words

Conflict resolution, African continent, displacement of persons; conflict in Darfur.
\end{abstract}

\section{Resumen}

Los conflictos en África en los últimos años han llevado a la pérdida de vidas humanas, el desplazamiento de personas y la miseria en muchas partes del continente. La necesidad de resolver, gestionar y prevenir estos conflictos, e igualmente frente a los desafíos socio-económicos derivados de estos s, se ha convertido en una fuente de preocupación para los países africanos como Nigeria, el gigante de África. Es a la luz de lo anterior que este artículo se propone analizar el papel de Nigeria en la resolución de conflictos en África, con la crisis del Darfur en Sudán como caso de estudio. El documento examina los antecedentes históricos del conflicto en Darfur y los esfuerzos realizados por Nigeria para resolver la crisis a través de iniciativas de paz. Ya que el restablecimiento de la paz en Darfur es un gran desafío que enfrenta el continente africano, el documento analiza los problemas y las perspectivas de paz en esa parte del continente.

El documento concluye que a pesar de que Nigeria haya demostrado su compromiso en la resolución del conflicto en Darfur, todavía tiene mucho que hacer, de concierto con la Unión Africana, sobre todo ahora que el sur de Sudán es un Estado soberano.

Palabras clave

Resolución de conflictos, continente africano, desplazamiento de personas, conflicto en Darfur.

\footnotetext{
* This paper attempts to analyze Nigeria's role in conflict resolution in Africa using the Darfur crisis in Sudan as a case study.

** Ph.D. Department of political science. University of Calabar. Calabar, Nigeria

Correo electrónico:

jcebegbulem@yahoo.com
} 


\section{Introduction}

The End of the cold war, especially in the 1990s and 2000s, coincidentally witnessed an accentuation in Africa of the incidence of intrastate conflicts - horizontally between different socio-ethnic and cultural aggregates within a national territory, and vertically between groups who feel excluded and marginalized from existing power structures on the one hand, and the central authority on the other (Egwu, 2007).

Since Nigeria got her independence in 1960 from Britain, Africa has been the centre-piece of her foreign policy. This is evidenced in the enormous human and material resources successive Nigerian governments had devoted in the prosecution of this cardinal foreign policy objective.

Within the West African sub-region, Nigeria has sought to manage the inter-state relations under the framework of the ECOWAS and other bilateral arrangements with its immediate neighbours. In this connection, it has made the promotion of peace and security the primary consideration, based on the convinction that economic development and regional integration cannot be superimposed on an unstable region.

Having championed the establishment of the Economic Community of West African States (ECOWAS) in 1975, Nigeria remained at the forefront of conflict resolution in the African continent. The country pushed for the prevention and resolution of devastating conflicts that engulfed Liberia, which spilled over to Sierra Leone. It is a historical fact today that Nigeria spearheaded the creation of ECOWAS Cease Fire Monitoring Group (ECOMOG) which facilitated the resolution of the civil wars, and the restoration of democracy in both countries. Nigeria has been able to learn her role in conflict resolutions in Africa that mediators in conflict situations must understand the precise nature of the conflict in terms of what issues are at stake and the various forces at play. This is why she was able to achieve much in Liberia and Sierra Leone.
Nigeria's role in conflict prevention and resolution is not limited to the West African subregion alone; it extends to other sub-regions of Africa. "Nigeria's contribution to the liberation/ independence of many African countries and to the end of apartheid in South Africa was widely acknowledged within and outside the continent. However, it is sad that these achievements have not put an end to political disquiet and conflicts in Africa. Rather, they seemed to have coincided with an upsurge in conflict situations." (Ugwu, 2008)

Nigeria is a firm believer in the indivisibility of peace and security in Africa. The country affirms that "a threat to peace anywhere in Africa is a threat to peace everywhere on the continent." By extension, any African nation at war and in distress is also a threat to world peace and security. Nigeria holds the view that Africa cannot meet the challenges of poverty reduction and the elimination of diseases, unless there is peace and security in Africa; hence her commitment in resolving the conflict in Darfur, Sudan.

Nigeria has committed both human and material resources in her effort to resolve the crisis in Darfur. The country organized several meditative meeting under the auspices of the African Union and the United Nations which resulted in the consensus on the Declaration of Principles in which the conflicting parties, namely the Central Sudanese Government and the Sudanese People's Liberation Movement agreed on the principle and conditions for self-determination for the Southern Sudan. The self determination of Southern Sudan today as an independent sovereign state is the dividend of many peace initiatives advanced by Nigeria intended to facilitate the resolution of the Darfur Crisis.

\section{Conflict: A conceptual discourse}

"Conflict is the pursuit of incompatible interest and goals by different groups. Armed conflict is the resort to the use of force and armed violence in the pursuit of incompatible 
and particular interest and goals." (Francis 2007) It is an inevitable product of cohabitation or co-existence of individuals or people in society struggling for limited values or resources as against countless desires.

In his conceptual approach, Bakut defines conflict as "the pursuit of incompatible goals or interests by different groups or individuals" (Bakut, 2007). According to him, all humans or groups of humans have goals and interests which may be different with the goals and interests of other groups. Sometimes conflicts become inevitable when these groups confront each other in the process of achieving their goals. It is noteworthy to understand that even though conflicts may be seen as a threat to peace, it is not all conflicts that are a threat to peace. It is only the negative action taken to resolve the conflict that represents the threat to peace. "The term 'negative' here connotes action that entails injuring other people or destroying their property in the attempt to resolve the conflict: for example, the use of arms (armed conflict) to resolve the conflict in one's favour which may result in mass killings, murder or even genocide of innocent and unarmed civilians." (Ibid)

Apart from negative conflict, we have what Aja Akpuru Aja calls functional or constructive conflict. Conflict is functional or constructive when it improves the quality of decision; it stimulates creativity and innovation; it encourages interests and curiosity among group members; it provides the medium through which problems can be aired and tensions released; it fosters an environment of self evaluation and improvement. (Aja, 2007)

The existence of scarce resources in societies often generates to fights over the distribution of these resources, and the fact that different interest groups in social systems pursue different goals and hence often had to vie with one another results to conflict.

In the international arena, governments seek to achieve some national objectives such as security, more territory, access to markets, prestige, alliances, and many other goals. In pursuing these goals, conflict may occur from incompatible positions over an issue. Conflict involves two or more nations or groups over divergent interests that are mutually antagonistic.

Conflict can occur as a result of the demand by one political group or nation-state for territorial right or resources controlled by another or the attempt by a nation-state to impose military, religious, political or economic controls over alien populations.

Conflicts emerge and continue until one party to the conflict withdraws its demands or induces the other party to collaborate and compromise or eventually compels the other party to submit through threats or military action.

International conflict could be caused by domestic rebellion which attracts outside intervention. In this type of internal-international conflict, there are usually more than two parties involved: the domestic government and the rebellious faction, and two or more outside powers intervening to support either of the parties or look for peaceful resolution of the conflict.

Suffice it to say that conflict is quite an indispensable but essential element of human relations. "It is an inescapable by-product of societal complexities and irreconcilable antagonisms found among humans." (Abia 2000) It involves tow or more parties in opposition to interests, principles, practice or strategies.

\section{Historical background of the Darfur conflict}

The conflict in Darfur appears like a recent development, but a deeper examination reveals that the crisis is deeply rooted in ages of resources and racial conflict between Durfurians of Arab and African descent. Conflicts usually occur between settled African farming communities and nomadic Arabs over grazing land and trampling of animals on food reserves 
and farms. In the past, successive Sudanese governments have continued to construe the crisis as resource based, deliberately excluding racial factor. However, since 2003, both racial and ethnic factors have played significant role in fuelling the current state of the conflict.

The Arabs who allegedly use state apparatus to ensure their dominance have continually shortchanged the people of the South, predominantly those of the African natives and of Christian faith in the process of resource distribution. The Southern Peoples Liberation Army (SPLA), as was constituted and run by John Garang was to form the platform that would be needed to mobilize the marginalized people of the South to seek the right of self-determination, a principle enshrined in the Charter of the United Nations, giving a people the leverage to determine the right to self rule (Achull, 2001). The resistance of the Sudanese government, and consequently her use of organized state violence to displace and deny the Southern people of their right for self-determination surely would be the focal point that would continue to provide reasons for the extended conflict in Sudan.

The conflict in Darfur began in February, 2003. Various rebel groups, due to alleged neglect and marginalization in the management of the affairs of the country, decided to take up arms against the central government in Sudan. The rebel groups are the Sudan Liberation Movement and the Justice and equality Movement (JEM). The Sudanese Government responded by attempting to inflict a total military defeat on the rebels. In the process, it allegedly armed the Janjaweed militia, to fight the government's cause. As a result of the fighting, many people, mostly civilians, have been killed, while over one million people have been displaced from their homes (Deng, 1995).

\section{Nigeria and conflict resolution in Africa}

While Nigeria has not been immune to the conflicts in Africa, having itself fought a devasta- ting civil war, suffered bad and oppressive governance under successive military regimes for most of its post independence history and currently battling with the Niger Delta crisis, it has not wavered in its commitment to conflict prevention, resolution and management in Africa. Successive Nigerian Governments, whether military or civilian democracy, had devoted enormous human and material resources to the prevention and resolution of conflicts in Africa.

As said earlier, having championed the establishment of the Economic Community of West African States (ECOWAS) in 1975, Nigeria remained at the forefront of conflict prevention and resolution in Africa. The country pushed for the prevention and resolution of devastating conflicts that engulfed many countries in the West African sub-region in particular and the African continent in general. It is not in doubt today that Nigeria was at the forefront in the creation of ECOWAS Cease Fire Monitoring Group (ECOMOG) which facilitated the resolution of the Liberian and Sierra Leonean crises and the restoration of democracy in both countries.

Under the sub-regional hegemony of Nigeria, the ECOWAS Ceasefire Monitoring Group (ECOMOG) was formed and deployed to some of the conflict zones as a regional peacekeeping and intervention force. ECOMOG's conflict resolution mechanism has mostly involved multidimensional peacekeeping i.e. traditional peacekeeping through monitoring implementation of peace agreements reached between conflicting parties. In addition to her role in ECOWAS' efforts in resolving conflict sin Africa, Nigeria has also been instrumental in most of the conflict mediation diplomacy and peace settlement agreements in almost all the recent wars in West Africa.

Nigeria has played a prominent role in the West African sub-region through the commitment of its substantial military capacity, notably in supplying the leadership and the majority of 
troops for ECOMOG, the ECOWAS-sponsored peace keeping force in Liberia. That operation was viewed as success, with armed conflict halted and elections held. During Abacha's administration, Nigerian troops were stationed in Sierra Leone to protect the country's borders from incursion of Liberian rebels. Nigeria also confronted a Sierra Leonean military junta that overthrew an elected civilian government, an action a bit ironic given the origin of the Abacha regime.

Nigeria exerted efforts to ensure that democratic governments were restored in Guinea-Bissau, Cote d'Ivoire, and Sao Tome and Principe, after the military take over in those countries. It has been speculated that Nigeria has so far spent over US\$10billion in peace campaigns, not to mention the large number of men and women of the Nigerian Armed Forces who paid the supreme sacrifice in the case of peace in the region.

Nigeria's role in peace-keeping, conflict prevention and resolution is not limited to the West African sub-region alone. This is exemplified by its previous engagements in $\mathrm{Chad}, \mathrm{Bu}-$ rundi, the D.R.C., Zimbabwe, Ethiopia - Eritrea and currently Darfur - Sudan, to mention but a few. The country has made the promotion of peace and security in Africa her primary foreign policy objective based on the convinction that economic development and regional integration cannot be superimposed on an unstable region.

The democracy and relative peace enjoyed by many African nations today would not have been possible if Nigerian peace makers had not fought to restore democracy in many of these nations, using the instrumentality of AU and ECOMOG.

\section{Nigeria's peace efforts in Sudan}

The resolution of the conflict in Darfur and the restoration of peace in that region was a major challenge to Nigeria as a power to be reckoned within continental politics. While the international community was still debating over the nature of the conflict in Darfur, Nigeria did not waste time in re-launching and injecting greater impetus to the search for peace in Darfur. Nigeria has always been actively involved in the search for peace in the Sudan.

As a first step in demonstrating Nigeria's commitment in resolving the conflict, the then president, Chief Olusegun Obasanjo deployed military expedition to Sudan, in line with Nigeria's spirit of good neighbourliness. The President canvassed for an African solution to the worsening humanitarian crisis in Darfur where the government-supported militia group, the Janjaweed has killed more than 300,000 nonArabs.

The principle of non-interference in the domestic affairs of member states of Organization of African Unity (O.A.U.) which prevented the Organization from putting pressure on the successive Sudanese government, dominated by the Arabs in the Northern part of Sudan, to refrain from carrying out policies that appear to be genocide against its own people, particularly the natives from the Southern Sudan was ignored by the A.U. under Obasanjo's leadership of the A.U. This paved the way for the A.U. and other members of the international community to get involved in finding a peaceful resolution to the Darfur crisis.

Beyond its pan-African policy of maintaining peace and security on the continent, Nigeria has additional reasons to be concerned about developments in the Sudan. The two countries share a long history of relations in Islamic learning and exchanges. It is believed that there are a large number of Sudanese Nigerian origins in Sudan, totaling about 3 million, many of who took permanent residence in the country. There are second and third generations of Nigerians whose ancestors left Nigeria in a bid to perform the Holy Pilgrimage to Saudi Arabia by land over the years. As a result of difficulties of making the long journeys in those days, 
many of these Nigerians had little or no alternative but to remain in Sudan (Ugwu, 2008).

Since the advent of the civil war in Southern Sudan in the early 1980s, Nigeria has been engaged in the search for peace in the country. It hosted series of Peace Talks in Lagos, Abuja and Kano in the late 1980s and early 1990s, all intended to facilitate the resolution of the longraging conflict. The seeds that have now germinated in the signing of a comprehensive Peace Accord between the Government of Sudan and the Sudan Peoples Liberation Movement (SPLM) were sown in those peace talks.

As a start in finding a peaceful resolution of the Darfur crisis, former President, Olusegun Obasanjo, while in office as President of Nigeria and AU Chairman appointed his predecessor in office, General Abdusalami Abubakar as his Special Envoy to Sudan. This appointment indicated Nigeria's poise for an active engagement in the Sudan, in a manner that was intended to inject credibility and sound judgment into the peace process.

After preliminary contacts, fact-finding missions and consultations with all stakeholders in the Darfur crisis, the first round of interSudanese Political Talks was convened in Abuja on August 23, 2004 under the auspices of the African Union. At the Peace Talk in Abuja, the Government of Sudan, the Sudan People's Liberation Movement (SPLM) and the Justice and Equality Movement (JEM) were all represented. Both political and humanitarian issues were raised and discussed at the Peace Talk.

According to George (2005), "one major lessons that Nigeria garnered in its various peace endeavours towards the resolution of the Darfur Crisis has been that mediators in conflict situations in Africa must understand the precise nature of the conflicts in terms of what issues are at stake, the claims and counter-claims of the parties, the various forces at play and the psychology of the combatants. Very often, outside in- terlocutors do not sufficiently take these matters into consideration. The result has been that their efforts have tended to achieve limited results."

Nigeria's hosting of series of peace talks between the Sudanese Government and the Sudanese People's Liberation Movement at various times in Abuja and other major cities in Nigeria is predicated on her efforts to understand the nature of the conflict after listening to the positions of both parties. George's assertion could be the major reason why Nigeria did not waste time in injecting greater impetus to the search for peace in Darfur while the international community was still debating over the nature of the conflict.

\section{Problems and prospects of peace in Darfur}

Restoring peace in Darfur is a huge challenge facing all concerned in the crisis. One of the fundamental challenges which faced a peaceful resolution of the conflict in Darfur is the activity of the government-sponsored Janjaweed, and the need to demobilize and disarm them. Another major problem to the resolution of the conflict is that the African Union Mission does not possess adequate instruments to meet the challenges in Darfur. The Mission is poorly funded and ill-equipped to effectively cover the entire area of Darfur. Many African countries are faced with domestic problems and challenges that they find it difficult to contribute troops or equipment. Those who have the personnel lack the means to deliver and maintain them. This brings us to the fact that the limited mandate of the A.U. force, logistical and financial troubles of the Organization, and the size of the force have made the A.U. Mission inefficient. The deployment of the AU force, even though small, took many months after the signing of the agreement by the Sudanese Government and the rebels. Moreover, even the limited mandate for monitoring the ceasefire agreement has not been effective. The mandate has no enforcement mechanism.

Now that Africa and the International Community have shown interest in the crisis in 
Darfur, which has witnessed loss of many lives, problems of refugees, famine leading to humanitarian catastrophe, it is important that attention ought not to be focused only on sending military missions and enforcing the imperative of disarmament among the warring factions, but attempts must be made to resolve the issues that are responsible for the lingering and destructive crisis in Darfur. An important issue here is the equitable distribution of resources of Sudan. The government has to negotiate with the rebel groups on this issue on a more serious and determined way. It has to be concerned with their feelings, demands and grievances and show more genuine commitments to satisfying them (Abel, 1990).

The Sudanese Government must unconditionally disarm the Janjaweed militia as a minimum condition for return to negotiation. While the impact of violence committed by both the army and the Janjaweed militia are worsening by the day, the Government of Sudan continues to distance itself from the activities of the militias. This is wrong.

On the part of the rebel forces, they should identify with and follow all negotiated attempts that are aimed at disarming them. Much as the government is duty bound to adopt means of stopping the use of arms and disarming the Janjaweed militia, the other rebel forces are also duty bound to immediately disarm as a starting gesture for further negotiations or observance of agreements reached in past negotiations. They should rather adopt a non-violent approach like peaceful demonstration, protest voting or pressure grouping to their demands.

In the continental arena, the A.U. should be involved as a continental peace making instrument. The organization has played insignificant role in restoring peace in Darfur. The A.U. mechanism for mediation as well as third party intervention should be reactivated and strengthened. Within Africa, majority of countries have so far remained supportive partners than peacemakers.
It is not surprising therefore, that these countries have sabotaged any genuine desire for restoring peace in Sudan within the A.U. framework.

Also of importance to peace restoration in Darfur is the need for the developed countries to refrain from indulging in the politics of oil, but rather allow the people to evolve efficient means of exploiting their oil reserves and equitably distributing their resources for the benefits of all the rest of the citizens without any discrimination on the grounds of sex, race or religion. In addition to this, the international community must come up with immediate strategies to alleviate the untold hardship presently ravaging the children, women and the brutalized people due to the long period of the crisis.

\section{Conclusion}

The enormous contributions of Nigeria to regional and sub-regional resolution of conflicts in Africa which cost the country billions of dollars and gallant men and women of the Nigerian Armed Forces who paid the supreme sacrifice in the cause of peace cannot be over emphasized.

Within the West African sub-region, Nigeria has made the promotion of peace and security her primary consideration under the framework of the Economic Community of West African States (ECOWAS). When Nigeria launched ECOMOG, the military arm of ECOWAS, in August 1991, nobody gave it the slightest chance of any significant success. Relative peace and democracy recorded presently in countries like Liberia, Sierra Leone, Chad, Cote d'Ivoire, to mention a few examples, would not have been possible without the determined fight put up by Nigerian peacemakers at huge human and material costs under the framework of AU and ECOMOG.

The Darfur Conflict is the cumulative aftermaths of ages of conflict and confrontation between rural ethnic, religious and socio-economic groups in Western Sudan. However, the 
conflict assumed its sordid degree of escalation following the rebellions that were started by SPLA and JEM in early 2003. The crisis occurred against the backdrop of the attempt by the Sudanese Government to use violence against civilian populations residing in Darfur who were suspected of supporting the rebellion. So far, the crisis has affected over a million civilians. Taken together, the crisis is a manifestation of a violent response by deprived Sudanese, those placed at the margin of state welfare and development.

Thus, to restore peace between the warring groups, Nigeria facilitated the signing of a comprehensive Peace Accord between the Sudanese Government and the Sudanese People's Liberation Movement (SPLM). Nigeria's strong commitment to finding a lasting solution to the lingering Sudanese conflict in Darfur must be seen in former President Obasanjo's appointment at different times, of General Abdusalami Abubakar, a former Nigerian Military Head of State, and Ambassador Baba Gana Kingibe, a former Foreign Affairs Minister of Nigeria as Special Envoys to Sudan.

Because of its volatility, there is an urgent need to find a lasting solution to the crisis in Darfur that will enable the affected people to return to normal life and the warring factions resolve their differences. Far from taking arms, resolving the crisis in Darfur requires genuine and creative initiatives and visions on the parts of the Sudanese Government, rebel forces, African countries and the International Community. Such solution requires both domestic and international goodwill as well as short and long term efforts.

Nigeria has demonstrated her commitment in resolving the conflict in Darfur by deploying military expedition to Sudan and hosting series of Peace Talks between the Sudanese Government and the rebel forces, she still has a lot to do in concert with the African Union, especially now that Southern Sudan is a sovereign state.

\section{References}

Abia, Victor (2000) "Contemporary Issues in International Relations”, Lagos: Concept Publications Ltd.

Aja, A. (2007) Basic Concepts, Issues and Strategies of Peace and Conflict Resolution. Owerri: Keny and Brothers Ent. (Nig.).

Alier, Abel (1990) "Southern Sudan: Too Many Agreements Dishonoured", Exeter: Ithaca Press.

Darfur in Flames: Atrocities in Western Sudan: http://www.hrw.org/reports/2004/sudan040

Darfur Monitoring Group 2005. "Ethnic Cleansing in Darfur Region of Sudan" www.d-a. org.Uk/pages/dmgl.htm

Deng, Francis Mading (1995) War of Visions: Conflicts of Identities in Sudan. Washington DC: The Brookings Institute.

Egwu, S. (2007) "Beyond Revival of Old Hatred: The State and Conflict in Africa", in Best, S. G. (ed), Introduction to Peace and Conflict Studies in West Africa. Ibadan: Spectrum Books.

Francis, D. (2007) "Peace and Conflict Studies: An African Overview of Basic Concepts", in best S. G. (ed) Introduction to Peace and Conflict Studies in West Africa. Ibadan: Spectrum Books.

Lual, Manock Achull (2001) "The Sudan: Prospects for a Peaceful Settlement of the Civil War" http://perce.ca/PEN/1992-03/achull.html

Pol, Mirjam (1998) "We have to sit down: Women, War and Peace in Southern Sudan". Utrecht, the Netherlands: Pax Christi.

Ude, Ugwu (2008) Nigeria's Father-Figure Role in Africa: The OAU-AU Example, Abakaliki: Smile Printing Press. 